\title{
The continuing relevance of strategy
}

\section{Anne Sigismund H uff}

$M$ y father-in-law understood what accounting was, or at least he was satisfied with his definition. He was much less sure about 'strategy', and I was not much help. It has never been easy for me to explain my field to others, although an example will sometimes suffice. 'Strategic decisions have longterm impact,' I said to my father-in-law a number of years ago. 'Your decision not to open a branch store in Aspen was strategic.'

This kind of definition can lead to further conversation, or stop it. 'I didn't realize it was so important at the time,' he might have said, giving me an entrée to M intzberg's (1978) arguments about realized strategy. Instead he dismissed my example by contending, 'I couldn't give it much thought, because I didn't have anyone who could handle it.' Unfortunately, I had not read Edith Penrose (1959) at the time.

I recently have had an increasing number of such unsatisfying conversations. Though I have much better stories to tell, I still worry that collectively we are falling short. Strategy is too often dismissed in this globalizing world of shifting alliances and instantaneous el ectronic connections as timeconsuming and irrelevant. I think one problem is definitional.

In the last several decades, organization behavior, organization theory, human relations and other areas of management inquiry have grown and developed, yet they do not seem to have had the difficulties defining their subject that we have had. The conversations we start, among ourselves and with others, are rarely brought to conclusion; they tend to falter in the face of new enthusiasms. The millennium is a good point to examine some of these starting points, and contemplate how we might further a fascinating, but elusive, area of inquiry. 


\section{What do strategists do?}

Strategy is about action. Verbs are therefore appropriate vehicles for summarizing our various foci of attention. Four in particular describe the post-World War II period in which business policy metamorphosed into strategy. They are interesting as contradictory yet complementary definitions of the field.

\section{Fight}

$\mathrm{H}$ istorians almost always point to our legacy from military strategy. From this point of view, the strategist identifies and analyzes the enemy, develops an overall campaign, hopefully chooses the battlefield, and orchestrates a sequence of encounters intended to achieve victory. Sun Tzu's insights from the sixth century BC continue to be relevant:

Warfare is the art (tao) of deceit. Therefore, when able, seem to be unable; when ready, seem unready; when nearby, seem far away, and when far away, seem near. ... A ttack where [the enemy] is not prepared; go by way of places where it would never occur to him that you would go.

(Sun Tzu, 1993, 104-5)

Porter $(1980,1990)$ used surprisingly similar ideas to help strategists think about their position with respect to suppliers and buyers, as well as competitors. Game theory now works to formalize such insights. The job is to vanquish or at least dominate an opponent. Relative profit is typically the measure of success. This perspective is relevant even to strategists in public and not-for-profit organizations, who must identify a purpose and way of operating that backers will find more deserving than other alternatives. These strategists find it easy to speak of the battle against cancer, or the arts' need to capture a larger share of recreational expenditures.

I think a military perspective has such widespread and enduring appeal because it makes valid statements about human nature. We like to win. The successful military strategist is cunning, but also taps the energies unleashed by threat and conflict. Adrenalin is a powerful, and addictive, force.

\section{Garden}

The definition of successful strategy that I learned first, however, was less combative. Pioneering work in business policy by Andrews (1971) and others emphasized that successful strategists must find a fit between the organization 
and its environment. As the strategy field gained momentum in the late 1970s, companies were investing large sums in environmental scanning and planning, academics were conducting large-scale studies of diversification and other strategic alternatives that provided empirical evidence for viable choices. The orientation was more developmental than combative.

Formal planning now has declined in appeal, and time horizons have shortened, yet Hamel and Prahalad (1994) are avoiding hand-to-hand combat when they urge companies to seek unexplored 'w hite spaces'. O ption theorists similarly are in a 'gardening' mode when they suggest small investments to keep multiple options alive under conditions of uncertainty. The overall idea, articulated by the resource-based view of the firm, is that success depends on skills and capabilities within the organization. Competitive advantage is still the aim, but learning and knowledge management (rather than gamesmanship) are the methodologies to follow.

This perspective on strategy also conforms to human nature. In our private as well as public lives, we seek patterns in order to make sense of our situation, and use them to actively position ourselves for desired results.

\section{Sustain}

It is easy to observe, however, that promising initiatives falter and that strategy implementation is much more difficult than strategy formulation. The forces of inertia are internal and external. Orchestrating activities in different parts of the organization and its larger environment takes time and leads to obligations that are not easily abandoned. $\mathrm{N}$ ew hires may be less committed to old initiatives and often bring new enthusiasms. A cross the organization, varied and often conflicting agendas tend to blur initial strategic coherence. Q uinn's (1978) work described why strategy is therefore logically incremental as it responds to different opportunities. Processual studies, such as those led by Pettigrew (e.g. 1991), provided additional insight into how organizational realities temper grand strategic ideas.

O ne sensible response, especially given the scale and scope of modern organizations, is to institutionalize success when it is achieved. $\mathrm{N}$ elson and Winter's (1982) work provides the rationale for routines that encapsulate the expertise of individuals and groups, and transcend their tenure. Prescriptions from the resource-based theory of the firm are compatible. The organizational resources required for sustained advantage are not only valuable, rare and inimitable, but also embedded in organizational processes (Barney, 1991).

Once again, these approaches to strategy are in accord with human nature. We base many actions on simplified conclusions from our own 
experience and the observation of others. If not, we would each be immobilized by choices faced before leaving for work. Woody Allen is said to have observed that 80 percent of success is just showing up. The sustained strategy that is homeostatically renewed over time follows the same logic.

Invent

On the other hand, previous experience is often inadequate. The opposite of routinization is invention. Insight has always been part of the strategy conversation, but it has recently become more salient. J obs and economic growth are more attributable to small start-up companies than we realized. Entrepreneurship courses are flourishing. A significant number of students now start or join e-commerce firms without even completing their degrees. These firms offer products, services and methods of delivery that are being identified for the first time. Q uinn et al. (1997), and other notable observers, have turned their attention to the need for innovation.

Interestingly, a key heroic moment, discovering strategy itself, typically takes place off stage. W inning strategic ideas are magic. We don't really know how they happen. At best we can talk about facilitating factors (money, time, training, infrastructure, etc.). But this definition also seems right. As a race, we have a history of extraordinary accomplishments achieved by people who somehow imagine what had been unimaginable.

\section{Do we need new ideas to strategize in a 'new economy'?}

O bviously, a more detailed discussion could be advanced and other areas of attention specified, but these four verbs indicate some important things about the field of business policy and strategy over the last 50 years or so. We have followed rather conflicting paths. In fact, we have participated in and fed the faddish search for direction that leads companies to adopt and then drop expensive enthusiasms. Re-engineering comes to mind; e-commerce is the currently consuming subject.

Pendulum swings, in academic as well as corporate concerns, do draw attention to the limits of past frameworks. Thus, the bounce is often corrective. E-commerce is not just about new technology, it also addresses consumer desires for comparison, autonomy, and more immediate gratification that were neglected by previous strategies.

$\mathrm{N}$ ew developments in academic theorizing have similarly redressed the limitations of past definitions. Despite the compelling nature of new 
arguments, however, I believe old accounts continue to be relevant, and easily justified by individual and organizational behavior. Intrinsically, strategy is not linear, and is likely to be even more complex under economic conditions that emphasize speed and facilitate change. We cannot expect to find one, simple focus of attention.

On the contrary, our efforts to date can be criticized for being too narrowly focused, even though we have offered needed diversity. Two limitations in particular need further attention. We have overly emphasized the rational, and under-emphasized the moral. The following verbs suggest ways of thinking about these neglected aspects of strategy. They point to a single cluster of concerns that are again contradictory, yet complementary.

\section{Husband}

It should not have been surprising that my father-in-law knew more about strategy and its long-term impacts than I realized. For example, while we were still in graduate school, he suggested that my husband and I buy a mountain cabin. It seemed expensive and somewhat peripheral to our lives, but we bought it and were glad to have vacations ready-made. I did not immediately appreciate, however, that J.0. was giving us more than financial and lifestyle advice. It was only after he died that I recognized he must have meant the cabin to be an anchor that would keep drawing us back to family. I am sure he had the idea our siblings and children would be more likely to return to Colorado with our cabin as an attractive magnet.

This kind of 'husbanding' is difficult to achieve in a global, hurry-up world, with widely accepted success formulas and pressures for immediate results. Responsibility for long-term consequences has not been emphasized in US-dominated strategies, though European and A sian publics and strategists tend to be more attentive. A s large companies eclipse more nation states, and both large and small companies find it easier to reinvent and relocate, I believe we should define strategy in ways that not only attend to longer-term implications of current strategy but also consider second-order effects. Faith in market mechanisms, in particular, must be reexamined in a world of imperfect markets. We should, I believe, become more responsible.

O ne point for departure in thinking about 'appropriate' strategy can be found in Etzioni's (1996) work on community, another in M ansbridge's (1990) edited book Beyond self-interest. Closer to home, Selznick's (1957) classic L eadership in administration argues for the importance of values and character. $M$ ore recent work on sustainable strategies is relevant, as is Peter Schwartz's (1991) book, The art of the long view. 


\section{Enact}

M ost of these works still fall within the rationalist mind-set that has dominated the strategy field. I believe it also is time to emphasize different epistemologies. Karl Weick $(1979,1995)$, who does not to my knowledge consider himself a strategy theorist, has done a good job of articulating the idea that the sense people make of their situations tends to enact the conditions they assume. Again, relevant issues are more widely discussed outside of the United States than within it (e.g. von Krogh \& Roos, 1996). A gain, a globalizing environment requires much more attention to enactment precisely because organizations are becoming so dominant.

Strategists have always changed the world in ways they could not fully anticipate. Surely, some leaders of the East India Companies considered the dramatic impact of their activities on the conditions of trade in the 1660s, though they could not comprehend all the conditions they were instrumental in enacting. Similar thoughts about consequences occupy contemporary the orists and strategists, yet in the end we tend to ignore the recursive aspects of strategy. We create campaigns to develop new markets, for example, but shy away from accepting responsibility for creating a world in the marketing campaign's image.

In my opinion, this is an urgent agenda for the immediate future, and one that requires reconsidering past definitions of strategy. Deceit is deeply ingrained in the military strategists' activities, for example; enactment suggests that it creates a world in which duplicity dominates trustworthy behavior. Every strategic perspective is similarly suspect. Inventors argue that any product they do not invent will be invented by others, to their profit and our loss. Thus, we are developing and beginning to market biological products with dramatic benefits but unknowable side-effects. Public debates on such difficult issues are increasing, but they are inconclusive. It is too easy for strategists, and strategy theorists, to consign such concerns to their private, rather than professional lives and confront the ironies implicit in their actions.

\section{Conclusion}

A few years ago it was asserted that the study of strategy could not progress unless we showed more discipline and decided on a limited number of key variables to focus our attention (M ontgomery et al., 1989). The argument makes some sense within a specific line of inquiry, over relatively limited periods of time. It is based, however, on a positivist view of scientific inquiry that is losing ground in other academic conversations, and is of limited relevance in the 'new economy' we should now be trying to understand. 
The strategy field can be praised for exploring some inherent tensions of purposeful action. We have considered conflict, but also cooperation and fit. We take invention as our domain, but also acknowledge the importance of routinization. The field thus establishes some compelling and interesting parameters for purposeful action.

$N$ onetheless, we still have work to do. Organizations create the conditions within which we all must live. Too many of us have resolutely looked away from the longer-term, social consequences of organizational activities. We have not acknowledged that strategy itself is implicated in the very conditions it tries to change. I hope that we confront these issues more directly in the years ahead. If we do so, we make an important bid for remaining relevant.

\section{References}

Andrews, K.R. The concept of corporate strategy. H omewood, IL: D ow-J ones Irwin, 1971. Barney, J.B. Firm resources and sustained competitive advantage. Journal of $\mathrm{M}$ anagement, 1991, 7, 99-120.

Etzioni, $\mathrm{A}$. The new golden rule: Community and morality in a democratic society. $\mathrm{N}$ ew York: Basic Books, 1996.

Hamel, G. \& Prahalad, C.K. Competing for the future. Boston, M A: Harvard Business School Press, 1994.

M ansbridge, J.J. Beyond self-interest. Chicago, IL: University of Chicago Press, 1990.

M intzberg, H. Patterns of strategy formation. M anagement Science, 1978, 24, 934-48.

M ontgomery, C.A., Wernerfelt, B. \& Balakrishnan, S. Strategy content and the research process: A critique and commentary. Strategic M anagement Journal, 1989, 10, 189-97.

N elson, R.R . \& Winter, S.G. An evolutionary theory of economic change. Cambridge: Cambridge University Press, 1982.

Penrose, E.T. The theory of the growth of the firm. N ew York: Wiley, 1959.

Pettigrew, A.M. Managing change for competitive success. Oxford: Oxford University Press, 1991.

Porter, M .E. Competitive strategy. N ew York: Free Press, 1980.

Porter, M .E. The competitive advantage of nations. N ew York: Free Press, 1990.

Q uinn, J.B. Strategic change: 'Logical incrementalism'. Sloan M anagement Review, 1978, Fall, 7-21.

Q uinn, J.B., Baruch, J.J . \& Zien, K.A. Innovation explosion: U sing intellect and software to revolutionize growth strategies. N ew York: Free Press, 1997.

Schwartz, P. The art of the long view. N ew York: Doubleday, 1991.

Selznick, P. Leadership in administration. Evanston, IL: Row, Peterson, 1957.

Sun Tzu. The art of war. (Translated, with an introduction and commentary, by Roger T. A mes.) N ew York: Ballantine, 1993.

Von Krogh, G. \& Roos, J. M anaging knowledge. London: Sage, 1996.

Weick, K.E. The social psychologizing of organizing. Reading, M A: Addison-Wesley, 1979.

Weick, K.E. Sensemaking in organizations. Thousand O aks, CA: Sage, 1995. 
Anne Sigismund Huffis Pro fessor of Strategic Management at the University of Colorado, Boulder, USA, with a joint appointment at Cranfield School of Management in the UK. She received her PhD from Northwestern University and has been on the faculty at UCLA and the University of Illinois. Her research interests focus on strategic change, both as a dynamic process of interaction among firms and as a cognitive process affected by the interaction of individuals over time. In addition to articles on various topics related to strategic change, her publications include Mapping strategic change (W iley, 1990), which discusses alternatives for visualizing strategic reasoning. Professor Huff's professional activities include serving on the editorial board of the Strategic $M$ anagement Journal, The Journal of Management Studies and The British Journal of $M$ anagement, and acting as the strategy editor for the book series 'Foundations in organization science' (Sage Publications). In 1998-9, she was President of the A cademy of Management.

[E-mail: Anne.H uff@ Colorado.edu] 